\title{
Language Awareness Among Undergraduate Sports Sciences Students
}

\author{
Ayse Demir (Corresponding author) \\ School of Physical Education and Sports, Siirt University, Turkey, \\ E-mail: aysemdemir@hotmail.com \\ Ezgi Inal \\ Faculty of Education \& TOMER, Istanbul Aydın University, Turkey \\ E-mail: ezgiinal1@aydin.edu.tr
}

Received: January 17, 2022 Accepted: February 21, 2022 Published: March 4, 2022

doi:10.5296/jei.v8i1.19471ＵRL: https://doi.org/10.5296/jei.v8i1.19471

\begin{abstract}
The ability of individuals to feel part of their culture highly depends on the extent to which they can use their native language and how they can manage linguistic processes. In this context, regardless of occupation or age, one needs to use the language in daily communication - an element maintaining the social order-correctly and in accordance with the language-specific rules. The aim of this study was to explore language awareness among undergraduate sports sciences students. A total of 205 students enrolled at schools of sports sciences in Istanbul, 64.9\% $(\mathrm{n}=133)$ were males and $35.1 \%(\mathrm{n}=72)$ were females, voluntarily participated in the research. We collected the data using a demographic information form and the "Everyday Language Awareness Scale". The 5-point Likert-type scale consists of 17 items within four sub-scales. While showing the frequencies of the responses to the scale items, we used an independent-samples t-test and one-way analysis of variance (ANOVA) to analyze the participants' scores by their demographics. We calculated Cronbach's alpha for the total score to be 0.86. Overall, we concluded that the participants had significantly higher awareness of the Turkish language by their total and subscale scores.
\end{abstract}

Keywords: Turkish, Language awareness, Sports sciences

\section{Introduction}

In its most general definition, language refers to a holistic system ensuring communication between people. In other words, language can be denoted as "a communication tool enabling 
the decomposition of human experience into units, namely, units of meaning, that is embodied with semantic content and sound expression, in ways that vary by communities" (Martinet, 1998 as cited in Gül \& Soysal, 2009).

Not only does a language undergo some changes in the historical process as a natural entity but it also affects one's life and is influenced by the cultural milieu to which it belongs. Moreover, said influence also takes place across cultures. However, considering the characteristics of world languages within intercultural influences, it can be asserted that the influence does not occur within specific characteristics of the language but rather between words as object descriptive elements. Therefore, words and phrases occupy an important place in the semantic layers of a language.

The increase in cultural and technological communication channels has accelerated the exchange between languages. In addition, bilingualism and multilingualism are now discussed from a broad perspective for similar reasons. The emergence of standard or different uses in a language directly depends on the needs, preferences, and language awareness of language users. Hence, the conscious sustainability of the pragmatic fields and unique characteristics of a language is again at the disposal and responsibility of its users, which is also closely associated with language awareness and functionality.

Language awareness may occur for a foreign language or mother tongue (Carter, 2003, p. 64). The aforementioned form of awareness enables one to realize the processes of deep learning and use of the characteristics of their own language and culture or other than their mother tongue. As a matter of fact, since the functioning of the mother tongue also helps to facilitate the functioning of a foreign language (Ellis, 2012, p. 4), language awareness and relevant studies are deemed necessary for every single individual.

Teaching Turkish as a native language and outcomes are designed to include pre-school language education. In addition, regardless of their program, everyone enrolling in higher education in Turkey must take Turkish language courses in each academic year of twelve-year compulsory education. In this respect, after graduation, people are expected to reach a certain language awareness and have a caring attitude toward the use of their mother tongue.

Schools of sports sciences are acknowledged as educational institutions which aim to provide students with professional competencies both at national and international levels and attempt to represent Turkey with successful athletes from different branches. Since language is the utmost indicator of culture and commitment, athletes with high language awareness are expected to have a high level of commitment to their cultural milieu and motivation for representation. Ultimately, the present study aimed to uncover everyday language awareness levels of sports sciences students.

\section{Method}

2.1 Design

The present study employed a descriptive survey design. Survey designs are among the 


\section{Macrothink}

research approaches aiming to describe a past or present situation as it is (Karasar, 2016).

\subsection{Population and Sample}

The research sample consisted of conveniently selected 205 sports sciences students in Istanbul, $64.9 \%(n=133)$ were males and $35.1 \%(n=72)$ were females.

\subsection{Data Collection Tools}

We collected the data from the participants via an online questionnaire. The first part of the questionnaire includes a demographic information form with questions about age, gender, university, department, and year of study. In the second part, we used the "Everyday Language Awareness Scale" (ELAS) to explore the everyday language awareness of the participants. Erol and Karakaya (2020) developed the 5-point Likert-type scale consisting of 17 items within four sub-scales: "Individual Awareness" (the first eight items), "Awareness in Social Media" items 9, 10, and 11), "Awareness in Everyday Life" (items 12, 13, and 14), and "Awareness in Mass Media" (items 15, 16, and 17).

\subsection{Data Analysis}

The distributions of the responses to the items were shown as frequencies. We calculated the total and subscale scores and explored them regarding normal distribution. Since the data showed a normal distribution, we analyzed the participants' total and subscale scores by their demographics using an independent samples t-test and one-way analysis of variance (ANOVA). While the reliability coefficient of the total score was 0.86 , we calculated alpha values of the subscales as follows 0.88 (Individual Awareness), 0.83 (Awareness in Social Media), 0.89 (Awareness in Everyday Life), and 0.78 (Awareness in Mass Media). We performed all statistical analyses using SPSS 20.0 at a $95 \%$ confidence level. 


\section{Findings}

\subsection{Demographics of the Participants}

Table 1. Demographic characteristics of the participants

\begin{tabular}{|c|c|c|c|}
\hline & & $\mathrm{n}$ & $\%$ \\
\hline \multirow{3}{*}{ Gender } & Male & 133 & 64.9 \\
\hline & Female & 72 & 35.1 \\
\hline & Total & 205 & 100.0 \\
\hline \multirow{4}{*}{ Age } & 18-19 years & 88 & 4.9 \\
\hline & 20-21 years & 70 & 34.1 \\
\hline & $21+$ years & 47 & 22.9 \\
\hline & Total & 205 & 100.0 \\
\hline \multirow{3}{*}{ University } & State university & 22 & 11.2 \\
\hline & Foundation university & 174 & 88.8 \\
\hline & Total & 196 & 100.0 \\
\hline \multirow{5}{*}{ Year of study } & 1 & 125 & 61.6 \\
\hline & 2 & 36 & 17.7 \\
\hline & 3 & 24 & 11.8 \\
\hline & 4 & 18 & 8.9 \\
\hline & Total & 203 & 100.0 \\
\hline
\end{tabular}

While $64.9 \%$ of the participants were males, $35.1 \%$ were females. Besides, $42.9 \%$ were $18-19$ years, $34.1 \%$ were $20-21$ years, and $22.9 \%$ were over 21 years. The rate of those enrolled at a state university was $11.2 \%$, it was $88.8 \%$ for studying at a foundation university. Finally, the majority of the students were freshmen $(61.6 \%)$, followed by juniors $(17.7 \%)$, sophomores (11.8\%), and seniors $(8.9 \%)$. 


\subsection{The Distribution of the Responses to the Items of the ELAS}

Table 2. Distribution of the responses to the items of the ELAS

\begin{tabular}{|c|c|c|c|c|c|c|c|c|c|c|}
\hline & \multicolumn{2}{|c|}{$\begin{array}{l}\text { Strongly } \\
\text { disagree }\end{array}$} & \multicolumn{2}{|c|}{ Disagree } & \multicolumn{2}{|c|}{ Neutral } & \multicolumn{2}{|c|}{ Agree } & \multicolumn{2}{|c|}{$\begin{array}{c}\text { Strongly } \\
\text { agree }\end{array}$} \\
\hline & $n$ & $\%$ & $n$ & $\%$ & $\mathrm{n}$ & $\%$ & $n$ & $\%$ & $\mathrm{n}$ & $\%$ \\
\hline $\begin{array}{l}\text { (1) I think that Turkish words should be derived to place } \\
\text { non-Turkish words. }\end{array}$ & 7 & $3.4 \%$ & 20 & $9.9 \%$ & 83 & $40.9 \%$ & 53 & $26.1 \%$ & 40 & $19.7 \%$ \\
\hline $\begin{array}{l}\text { (2) The use of our language with foreign word patterns } \\
\text { damages our language (For example, Cafe Sorgun, Otel } \\
\text { The Yozgat, etc.). }\end{array}$ & 9 & $4.4 \%$ & 36 & $17.6 \%$ & 46 & $22.4 \%$ & 55 & $26.8 \%$ & 59 & $28.8 \%$ \\
\hline $\begin{array}{l}\text { (3) Speaking with only Turkish words and words } \\
\text { translated into Turkish is an indication of backwardness. }\end{array}$ & 58 & $28.3 \%$ & 71 & $34.6 \%$ & 41 & $20.0 \%$ & 29 & $14.1 \%$ & 6 & $2.9 \%$ \\
\hline $\begin{array}{l}\text { (4) I warn my friends who use foreign words despite } \\
\text { having Turkish equivalents while having a conversation. }\end{array}$ & 40 & $19.5 \%$ & 61 & $29.8 \%$ & 51 & $24.9 \%$ & 38 & $18.5 \%$ & 15 & $7.3 \%$ \\
\hline $\begin{array}{l}\text { (5) When I come across a foreign word in a text I read, I } \\
\text { look up its Turkish equivalent from the dictionary. }\end{array}$ & 12 & $5.9 \%$ & 30 & $14.7 \%$ & 66 & $32.4 \%$ & 67 & $32.8 \%$ & 29 & $14.2 \%$ \\
\hline $\begin{array}{l}\text { (6) I think that as individuals, we should speak Turkish } \\
\text { properly in our daily lives. }\end{array}$ & 2 & $1.0 \%$ & 2 & $1.0 \%$ & 23 & $11.3 \%$ & 60 & $29.4 \%$ & 117 & $57.4 \%$ \\
\hline $\begin{array}{l}\text { (7) Wearing clothes with foreign words on them makes } \\
\text { me uncomfortable. }\end{array}$ & 109 & $53.2 \%$ & 69 & $33.7 \%$ & 17 & $8.3 \%$ & 4 & $2.0 \%$ & 6 & $2.9 \%$ \\
\hline $\begin{array}{l}\text { (8) It bothers me if a text I read has foreign words used } \\
\text { despite having Turkish equivalents. }\end{array}$ & 33 & $16.2 \%$ & 56 & $27.5 \%$ & 55 & $27.0 \%$ & 42 & $20.6 \%$ & 18 & $8.8 \%$ \\
\hline $\begin{array}{l}\text { (9) The use of letters that are not in our alphabet (w, q, x) } \\
\text { in social media bothers me (For example, wadi instead of } \\
\text { vadi, etc.). }\end{array}$ & 36 & $17.6 \%$ & 48 & $23.5 \%$ & 28 & $13.7 \%$ & 48 & $23.5 \%$ & 44 & $21.6 \%$ \\
\hline $\begin{array}{l}\text { (10) I warn my friends who misspell Turkish words on } \\
\text { social media. }\end{array}$ & 23 & $11.3 \%$ & 37 & $18.1 \%$ & 64 & $31.4 \%$ & 45 & $22.1 \%$ & 35 & $17.2 \%$ \\
\hline $\begin{array}{l}\text { (11) I approve the use of abbreviated words (For } \\
\text { example, mrb instead of merhaba, etc.). }\end{array}$ & 72 & $35.3 \%$ & 47 & $23.0 \%$ & 35 & $17.2 \%$ & 23 & $11.3 \%$ & 27 & $13.2 \%$ \\
\hline $\begin{array}{l}\text { (12) I feel uncomfortable when I see foreign names given } \\
\text { to the main roads and streets. }\end{array}$ & 30 & $14.7 \%$ & 53 & $26.0 \%$ & 40 & $19.6 \%$ & 40 & $19.6 \%$ & 41 & $20.1 \%$ \\
\hline $\begin{array}{l}\text { (13) I am not bothered by seeing signs written with } \\
\text { foreign words around me. }\end{array}$ & 42 & $20.6 \%$ & 37 & $18.1 \%$ & 59 & $28.9 \%$ & 47 & $23.0 \%$ & 19 & $9.3 \%$ \\
\hline $\begin{array}{l}\text { (14) I am bothered by seeing workplaces with foreign } \\
\text { names around me. }\end{array}$ & 29 & $14.4 \%$ & 58 & $28.7 \%$ & 61 & $30.2 \%$ & 26 & $12.9 \%$ & 28 & $13.9 \%$ \\
\hline $\begin{array}{l}\text { (15) It is not important for me whether the language in } \\
\text { the mass media is used in accordance with the rules of } \\
\text { language. }\end{array}$ & 47 & $23.2 \%$ & 65 & $32.0 \%$ & 65 & $32.0 \%$ & 18 & $8.9 \%$ & 8 & $3.9 \%$ \\
\hline $\begin{array}{l}\text { (16) I feel uncomfortable that the Turkish pronunciation } \\
\text { of foreign words used in mass media changes from } \\
\text { person to person in Turkish. }\end{array}$ & 18 & $8.8 \%$ & 62 & $30.4 \%$ & 67 & $32.8 \%$ & 39 & $19.1 \%$ & 18 & $8.8 \%$ \\
\hline $\begin{array}{l}\text { (17) Programs with excessive use of local dialects should } \\
\text { be expanded. }\end{array}$ & 11 & $5.5 \%$ & 43 & $21.4 \%$ & 88 & $43.8 \%$ & 38 & $18.9 \%$ & 21 & $10.4 \%$ \\
\hline
\end{tabular}




\section{$\Lambda$ Macrothink}

The rate of those who did not strongly agree with the statement "I think that Turkish words should be derived to place non-Turkish words" was 3.4\%. While $9.9 \%$ and $40.9 \%$ did not agree or remained neutral with the item, respectively, $26.1 \%$ and $19.7 \%$ agreed and strongly agreed with the statement, respectively.

To the item "The use of our language with foreign word patterns damages our language (For example, Cafe Sorgun, Otel The Yozgat, etc.)," 4.4\% gave the response "Strongly disagree," 17.6\% "Disagree," 22.4\% "Neutral," 26.8\% “Agree," and 28.8\% “Strongly agree."

While $28.3 \%$ strongly disagreed with the item "Speaking with only Turkish words and words translated into Turkish is an indication of backwardness," it was 34.6\% for those not agreeing with the item. Besides, 20\% remained neutral with the statement. In contrast, the rates of those agreeing and strongly agreeing with the item were $14.1 \%$ and $2.9 \%$, respectively.

The rate of those who did not strongly agree with the statement "I warn my friends who use foreign words despite having Turkish equivalents while having a conversation" was $19.5 \%$. While $29.8 \%$ and $24.9 \%$ did not agree or remained neutral with the item, respectively, $18.5 \%$ and $7.3 \%$ agreed and strongly agreed with the statement, respectively.

To the item "When I come across a foreign word in a text I read, I look up its Turkish equivalent from the dictionary," 5.9\% gave the response "Strongly disagree," 14.7\% "Disagree," 32.4\% "Neutral," 32.8\% "Agree," and 14.2\% "Strongly agree."

While 1\% strongly disagreed with the item "I think that as individuals, we should speak Turkish properly in our daily lives," it was $1 \%$ for those not agreeing with the item. Besides, $11.3 \%$ remained neutral with the statement. In contrast, the rates of those agreeing and strongly agreeing with the item were $29.4 \%$ and $57.4 \%$, respectively.

The rate of those who did not strongly agree with the statement "Wearing clothes with foreign words on them makes me uncomfortable" was $53.2 \%$. While $33.7 \%$ and $8.3 \%$ did not agree or remained neutral with the item, respectively, $2 \%$ and $2.9 \%$ agreed and strongly agreed with the statement, respectively.

To the item "It bothers me if a text I read has foreign words used despite having Turkish equivalents," 16.2\% gave the response "Strongly disagree," 27.5\% "Disagree," 27\% "Neutral," $20.6 \%$ "Agree," and 8.8\% "Strongly agree."

While $17.6 \%$ strongly disagreed with the item "The use of letters that are not in our alphabet (w, $\mathrm{q}, \mathrm{x}$ ) in social media bothers me (For example, wadi instead of vadi, etc.)," it was $23.5 \%$ for those not agreeing with the item. Besides, $13.7 \%$ remained neutral with the statement. In contrast, the rates of those agreeing and strongly agreeing with the item were $23.5 \%$ and $21.6 \%$, respectively.

The rate of those who did not strongly agree with the statement "I warn my friends who misspell Turkish words on social media" was $11.3 \%$. While $18.1 \%$ and $31.4 \%$ did not agree or remained neutral with the item, respectively, $22.1 \%$ and $17.9 \%$ agreed and strongly agreed with the statement, respectively. 


\section{Macrothink}

To the item "I approve the use abbreviated words (For example, mrb instead of merhaba, etc.)," $35.3 \%$ gave the response "Strongly disagree," 23\% "Disagree," 17.2\% "Neutral," $11.3 \%$ "Agree," and 13.2\% "Strongly agree."

While $14.7 \%$ strongly disagreed with the item "I feel uncomfortable when I see foreign names given to the main roads and streets," it was $26 \%$ for those not agreeing with the item. Besides, $19.6 \%$ remained neutral with the statement. In contrast, the rates of those agreeing and strongly agreeing with the item were $19.6 \%$ and $20.1 \%$, respectively.

The rate of those who did not strongly agree with the statement "I am not bothered by seeing signs written with foreign words around me." was 20.6\%. While $18.1 \%$ and $28.9 \%$ did not agree or remained neutral with the item, respectively, $23 \%$ and $9.3 \%$ agreed and strongly agreed with the statement, respectively.

To the item "I am bothered by seeing workplaces with foreign names around me.," $14.4 \%$ gave the response "Strongly disagree," 28.7\% "Disagree," 30.2\% "Neutral," 12.9\% "Agree," and $13.9 \%$ "Strongly agree."

While $23.2 \%$ strongly disagreed with the item "It is not important for me whether the language in the mass media is used in accordance with the rules of language," it was $32 \%$ for those not agreeing with the item. Besides, 32\% remained neutral with the statement. In contrast, the rates of those agreeing and strongly agreeing with the item were $8.9 \%$ and $3.9 \%$, respectively.

The rate of those who did not strongly agree with the statement "I feel uncomfortable that the Turkish pronunciation of foreign words used in mass media change from person to person in Turkish" was $8.8 \%$. While $30.4 \%$ and $32.8 \%$ did not agree or remained neutral with the item, respectively, $19.1 \%$ and $8.8 \%$ agreed and strongly agreed with the statement, respectively.

To the item "Programs with excessive use of local dialects should be expanded," $5.5 \%$ gave the response "Strongly disagree," 21.4\% "Disagree," 43.8\% "Neutral," 18.9\% "Agree," and 10.4\% "Strongly agree."

\subsection{Relationships Between the Participants' Language Awareness and Their Demographics}

We explored associations between the participants' mean subscale and total scores and their demographics using an independent samples t-test and one-way analysis of variance (ANOVA). The results are summarized below. 
Table 3. Language awareness by gender

\begin{tabular}{|c|c|c|c|c|c|c|}
\hline \multicolumn{2}{|l|}{ Gender } & $\mathrm{N}$ & M & SD & $\mathrm{t}$ & $\mathrm{p}$ \\
\hline \multirow{2}{*}{ Individual Awareness } & Male & 133 & 3.19 & 0.54 & \multirow{2}{*}{-0.507} & \multirow{2}{*}{0.613} \\
\hline & Female & 72 & 3.23 & 0.53 & & \\
\hline \multirow{2}{*}{ Awareness in Social Media } & Male & 133 & 3.17 & 0.92 & \multirow{2}{*}{-1.711} & \multirow{2}{*}{0.089} \\
\hline & Female & 72 & 3.40 & 0.92 & & \\
\hline \multirow{2}{*}{ Awareness in Everyday Life } & Male & 133 & 2.96 & 0.94 & \multirow{2}{*}{-0.781} & \multirow{2}{*}{0.436} \\
\hline & Female & 72 & 3.07 & 0.97 & & \\
\hline \multirow{2}{*}{ Awareness in Mass Media } & Male & 133 & 3.21 & 0.73 & \multirow{2}{*}{0.091} & \multirow{2}{*}{0.928} \\
\hline & Female & 72 & 3.20 & 0.58 & & \\
\hline \multirow{2}{*}{ Total Score } & Male & 133 & 3.16 & 0.43 & \multirow{2}{*}{-1.050} & \multirow{2}{*}{0.295} \\
\hline & Female & 72 & 3.23 & 0.44 & & \\
\hline
\end{tabular}

The t-test results revealed that the participants' mean language awareness scores (total and subscale scores) did not differ significantly by gender. In other words, male and female participants had similar levels of general language awareness (Table 3). 


\section{Macrothink}

Table 4. Language awareness by gender

\begin{tabular}{|c|c|c|c|c|c|c|}
\hline \multicolumn{2}{|l|}{ Age } & $\mathrm{N}$ & $\mathrm{M}$ & SD & $F$ & $\mathrm{p}$ \\
\hline \multirow{4}{*}{ Individual Awareness } & $18-19$ & 88 & 3.10 & 0.53 & \multirow{4}{*}{6.655} & \multirow{4}{*}{$0.002 *$} \\
\hline & $20-21$ & 70 & 3.18 & 0.52 & & \\
\hline & $21+$ & 47 & 3.44 & 0.51 & & \\
\hline & Total & 205 & 3.21 & 0.54 & & \\
\hline \multirow{4}{*}{ Awareness in Social Media } & $18-19$ & 88 & 3.10 & 0.83 & \multirow{4}{*}{2.828} & \multirow{4}{*}{0.061} \\
\hline & $20-21$ & 70 & 3.28 & 0.98 & & \\
\hline & $21+$ & 47 & 3.48 & 0.96 & & \\
\hline & Total & 205 & 3.25 & 0.92 & & \\
\hline \multirow{4}{*}{ Awareness in Everyday Life } & $18-19$ & 88 & 2.87 & 0.90 & \multirow{4}{*}{5.071} & \multirow{4}{*}{$0.007 *$} \\
\hline & $20-21$ & 70 & 2.91 & 0.90 & & \\
\hline & $21+$ & 47 & 3.38 & 1.04 & & \\
\hline & Total & 205 & 3.00 & 0,95 & & \\
\hline \multirow{4}{*}{ Awareness in Mass Media } & $18-19$ & 88 & 3.29 & 0,59 & \multirow{4}{*}{1.288} & \multirow{4}{*}{0.278} \\
\hline & $20-21$ & 70 & 3.13 & 0,73 & & \\
\hline & $21+$ & 47 & 3.15 & 0,74 & & \\
\hline & Total & 205 & 3.20 & 0,68 & & \\
\hline \multirow{4}{*}{ Total Score } & 18-19 & 88 & 3.09 & 0,40 & \multirow{4}{*}{7.627} & \multirow{4}{*}{$0.001^{*}$} \\
\hline & $20-21$ & 70 & 3.16 & 0,42 & & \\
\hline & $21+$ & 47 & 3.39 & 0,45 & & \\
\hline & Total & 205 & 3.18 & 0,43 & & \\
\hline
\end{tabular}

The ANOVA results showed the participants' mean total scores and scores on the subscales "Individual Awareness" and "Awareness in Everyday Life" significantly differed by age $(\mathrm{p}<$ 0.05). We performed a Tukey post hoc test to reveal the source of the difference and found that those aged 21 years and over had significantly higher total and subscale scores than the participants in other age groups (Table 4). 


\section{Macrothink}

Table 5. Language awareness by university

\begin{tabular}{|c|c|c|c|c|c|c|}
\hline \multicolumn{2}{|l|}{ University } & $\mathrm{N}$ & M & $\mathrm{SD}$ & $\mathrm{t}$ & $\mathrm{p}$ \\
\hline \multirow{2}{*}{ Individual Awareness } & State University & 22 & 3.35 & 0.50 & \multirow{2}{*}{1.239} & \multirow{2}{*}{0.217} \\
\hline & Foundation University & 174 & 3.20 & 0.54 & & \\
\hline \multirow{2}{*}{ Awareness in Social Media } & State University & 22 & 3.62 & 1.05 & \multirow{2}{*}{2.012} & \multirow{2}{*}{$0.046^{*}$} \\
\hline & Foundation University & 174 & 3.20 & 0.91 & & \\
\hline \multirow{2}{*}{ Awareness in Everyday Life } & State University & 22 & 3.29 & 1.12 & \multirow{2}{*}{1.468} & \multirow{2}{*}{0.144} \\
\hline & Foundation University & 174 & 2.97 & 0.94 & & \\
\hline \multirow{2}{*}{ Awareness in Mass Media } & State University & 22 & 3.12 & 0.70 & \multirow{2}{*}{-0.606} & \multirow{2}{*}{0.545} \\
\hline & Foundation University & 174 & 3.22 & 0.69 & & \\
\hline \multirow{2}{*}{ Total Score } & State University & 22 & 3.35 & 0.44 & \multirow{2}{*}{1.786} & \multirow{2}{*}{0.076} \\
\hline & Foundation University & 174 & 3.17 & 0.44 & & \\
\hline
\end{tabular}

Note. ${ }^{*} \mathrm{p}<0.05$.

Moreover, we investigated whether language awareness of the participants by their universities. Accordingly, the results demonstrated that the participants' scores on only the "Awareness in Social Media" significantly differed by university $(p<0.05)$. Therefore, language awareness in social media among those enrolled at a state university was significantly higher than those studying at a foundation university (Table 5). 
Table 6. Language awareness by year of study

\begin{tabular}{|c|c|c|c|c|c|c|}
\hline \multicolumn{2}{|l|}{ Year of study } & $\mathrm{N}$ & M & SD & $\mathrm{F}$ & $\mathrm{p}$ \\
\hline \multirow{5}{*}{ Individual Awareness } & 1 & 125 & 3.14 & 0.51 & \multirow{5}{*}{2.318} & \multirow{5}{*}{0.077} \\
\hline & 2 & 36 & 3.23 & 0.60 & & \\
\hline & 3 & 24 & 3.40 & 0.60 & & \\
\hline & 4 & 18 & 3.38 & 0.41 & & \\
\hline & Total & 203 & 3.21 & 0.54 & & \\
\hline \multirow{5}{*}{ Awareness in Social Media } & 1 & 125 & 3.16 & 0.83 & \multirow{5}{*}{1.084} & \multirow{5}{*}{0.357} \\
\hline & 2 & 36 & 3.27 & 1.08 & & \\
\hline & 3 & 24 & 3.49 & 1.03 & & \\
\hline & 4 & 18 & 3.41 & 1.01 & & \\
\hline & Total & 203 & 3.24 & 0.92 & & \\
\hline \multirow{5}{*}{ Awareness in Everyday Life } & 1 & 125 & 2.97 & 0.93 & \multirow{5}{*}{2.019} & \multirow{5}{*}{0.112} \\
\hline & 2 & 36 & 2.82 & 0.99 & & \\
\hline & 3 & 24 & 3.17 & 0.90 & & \\
\hline & 4 & 18 & 3.45 & 1.07 & & \\
\hline & Total & 203 & 3.01 & 0.95 & & \\
\hline \multirow{5}{*}{ Awareness in Mass Media } & 1 & 125 & 3.28 & 0.59 & \multirow{5}{*}{2.320} & \multirow{5}{*}{0.077} \\
\hline & 2 & 36 & 2.98 & 0.81 & & \\
\hline & 3 & 24 & 3.21 & 0.86 & & \\
\hline & 4 & 18 & 3.02 & 0.61 & & \\
\hline & Total & 203 & 3.20 & 0.68 & & \\
\hline \multirow{5}{*}{ Total Score } & 1 & 125 & 3.14 & 0.42 & \multirow{5}{*}{2.244} & \multirow{5}{*}{0.084} \\
\hline & 2 & 36 & 3.16 & 0.42 & & \\
\hline & 3 & 24 & 3.34 & 0.52 & & \\
\hline & 4 & 18 & 3.33 & 0.40 & & \\
\hline & Total & 203 & 3.18 & 0.43 & & \\
\hline
\end{tabular}

Table 6 presents the ANOVA results regarding the relationship between the language awareness scores of the participants and their year of study. Thus, their language awareness did not significantly differ by their year of study $(p>0.05)$. Namely, the participants in 
different years of study had similar levels of language awareness.

\section{Discussion, Conclusion and Recommendations}

Our findings revealed that the participants' language awareness significantly differed by their gender and year of study. In addition, we found that those aged 21 years and over had higher language awareness than others. Finally, the students enrolling at a state university had higher scores on the "Awareness in Social Media" subscale than their counterparts studying at a foundation university.

Overall, while the participants had high self-awareness regarding the correct use and preference of Turkish, their language awareness was moderate in social media and high in mass media, respectively. On the other hand, we concluded an interesting finding in terms of language awareness in everyday life. While participants were often positive for foreign-origin names on streets, avenues, and signboards, they reported negative opinions about workplaces with signboards in a foreign language. In this context, we may assert that language awareness should be discussed together with cultural awareness since it covers both sociological and psychological processes. Language awareness is also essential regarding intralinguistic and extralinguistic functions in the dialects of the same language (Sar1, 2021), which coincides with our results related to language awareness in mass media.

Language awareness is acquired intuitively rather than being learned in a class and is closely linked with several skills (Şeref \& Varışoğlu, 2020, p. 960). Therefore, such an acquisition includes a state of consciousness spreading over time, which not only provides a cognitive advantage on the language but also creates attitudes toward it depending on the level of awareness. Besides, language awareness is emphasized as an important part of teacher education (Carter, 2003, p. 64). In addition, in line with the focus of this study, the literature host many studies on awareness of Turkish language (Kolaç, 2008; Yücel, 2009; Erdoğan, 2011; Aslan \& K1lıç, 2012; Sayar \& Turan, 2012; Göçer, 2013; Karakaş, Türkan, \& Özdemir, 2013; Batur \& Beyret, 2015; Doğan, 2016; Arslan, 2017; Bağc1 Ayranc1, 2017; Şenyuva, Ertüzün, Turan, \& Demir, 2017; Şeref \& Varışoğlu, 2020) as well as attitudes toward Turkish language (Alan \& Bağc1, 2016; Koçak \& Şimşek, 2020; Toptal, Türkay, \& Ar1, 2020). In general, we may propose that our findings overlap what was found in these studies.

Based on our findings, we think that,

> All occupational groups and social segments should be recruited to language awareness practices;

$>$ The number of workshops and informative meetings for language awareness needs to be increased;

> Language awareness works should be visible on social media platforms;

> Society needs to be informed that interculturalism can only be built on mother tongue awareness; 
$>$ International collaborations and projects on language awareness should be on the agenda;

> Universities should increase their studies on language awareness;

$>$ Relevant projects should be kicked off to introduce children and young people with the opportunity to increase their mother tongue awareness.

\section{References}

Alan, N., \& Bağc1, H. (2016). Evaluation on the Behaviors of the University Students through Turkish Language. Mehmet Akif Ersoy University Journal of Faculty of Education, 1(38), 118-132.

Arslan, M. (2017). Problems Encountered in the Development of Turkish as A Native Language Teaching and Basic Language Skills. The Journal of Academic Social Science, 5(46), 63-77. https://doi.org/10.16992/ASOS.12256

Aslan, A., \& Kılıç, Y. (2012). A Study on Measurement of Turkish Consciousness Levels of Turkish Teachers and Teacher Candidates (The Sample of Agri Province). Turkish Studies-International Periodical for the Languages, Literature and History of Turkish or Turkic, 7(4), 799-806. https://doi.org/10.7827/TurkishStudies.4078

Bağc1-Ayranc1, B. (2017). Current Problems of Turkish According to Teacher Candidates. International Journal of Language Academy, 5(2), 63-78.

Batur, Z., \& Beyret, T. N. (2015). Relationship between metalinguistic awareness skills and writing skills of middle school students. Electronic Turkish Studies, 10(15), 873-892. https://doi.org/10.7827/TurkishStudies.8982

Carter, R. (2003). Language awareness. ELT Journal, 57(1), 64-65. https://doi.org/10.1093/ elt/57.1.64

Doğan, Y. (2016). Examination of Prep-Class Students' Metacognitive Awareness, Self-Efficacy Beliefs, Foreign Language Anxiety Levels, Foreign Language Attitudes and Academic Achievement in Foreign Language ( $\mathrm{PhD}$ Thesis, Institute of Education, Frat University, Elazı ̆̆).

Ellis, E. M. (2012). Language awareness and its relevance to TESOL. University of Sydney Papers in TESOL, 7, 1-23.

Erdoğan, Ö. (2011). An Important Skill for First Reading-Writing Process: Phonological Awareness. Uludă̆ University Faculty of Education Journal, 24(1), 161-180.

Erol, M., \& Karakaya, İ. (2020). Development of Language Awareness Scale regarding Daily Life. International Journal of Assessment Tools in Education, 7(4), 535-548. https://doi.org/ 10.21449/ijate.647488

Göçer, A. (2013). Contemporary Issues of Turkish According To Turkish Student Teachers. Adlyaman University Journal of Social Sciences Institute Special Issue of Teaching Turkish 
Education, 6(11), 491-515.

Gül, F., \& Soysal, B. (2009). On The Relation of Language and Thought. Journal of Social Sciences Research, 7(13), 65-76.

Karakas, O., Turkan, A. H., \& Ozdemir, Ş. (2013). A Research on Sensitivity of University Students to Degeneration of Language: Case Study of Afyonkarahisar. Electronic Turkish Studies, 8(4), 927-937.

Karasar, N. (2016). Scientific Research Method (31st ed.). Ankara: Nobel Akademik Yayıncilik.

Kolaç, E. (2008). Candidate Primary School Teachers' Awareness of the Problems Affecting Our Mother Tongue: Opinions and Suggestions. International Journal of Social Studies, $1(15), 441-455$.

Kolçak, Ş., \& Şimşek, N. D. (2020). Investigation of Student Attitudes towards the Common Turkish Language Course at the University. Pearson Journal of Social Sciences-Humanities, 7, 389-397.

Sar1, İ. (2021). Intra-Linguistic and Extra-Linguistic Functions of Dialects. Journal of Language Studies, 15(29), 55-66.

Sayar, F., \& Turan, F. (2012). The Effect of metalanguage Awareness, Phonological Processes and Memory Processes in Reading Development: Short-term Memory and Working Memory. Ankara University Faculty of Educational Sciences Journal of Speciaş Education, 13(2), 49-67.

Şenyuva, E., Ertüzün, F., Turhan, K., \& Demir, N. (2017). Turkish Language Problems, Solution Recommendation and Turkish Conscience: Intergeneration Comparison. International Journal of Turkish Literature Culture Education, 6(3), 1384-1397. https://doi.org/10.7884/teke.3959

Şeref, İ., \& Varışoğlu, B. (2020). The investigation into prospective teachers' Turkish metalinguistic awareness. Journal of Language and Linguistic Studies, 16(2), 959-977. https://doi.org/10.17263/j1ls.759351

Toptal, G., Turkay, H., \& Arı, Ç. (2020). Investigation of The Attitudes Of Sport Science Students On Turkish I Written Expression Course. International Anatolian Social Sciences Journal, 4(2), 30-40.

Yucel, D. (2009). Investigation of the Effect of Phonological Awareness (Phonological Awareness) Education on Children with Reading Problems (Unpublished MSc thesis, Hacettepe University, Ankara).

\section{Copyright Disclaimer}

Copyright for this article is retained by the author(s), with first publication rights granted to 
the journal.

This is an open-access article distributed under the terms and conditions of the Creative Commons Attribution license (http://creativecommons.org/licenses/by/3.0/). 